\title{
The biochemistry of the basal ganglia and Parkinson's disease*
}

\author{
G. Curzon \\ Ph.D., D.Sc. \\ Department of Neurochemistry, Institute of Neurology, London WC1
}

\begin{abstract}
Summary
The metabolic pathways for five transmitters in the basal ganglia are briefly described; the results of determinations of their concentrations, of their rate-limiting enzymes and of their degradation products are summarized.

The changes found in Parkinson's disease are described. While dopamine synthesis in the basal ganglia is defective in this condition, abnormalities of other transmitters occur, and their possible significance is discussed.
\end{abstract}

\section{Introduction}

How our understanding of Nature advances may be pictured in terms of a sequence of boxes in which new knowledge on a particular topic can be stored, at first appropriately but eventually with decreasing appropriateness until finally the box breaks apart and a new box-a new way of looking at the topicis set up. This remains acceptable for a time until eventually it also breaks down-and so on.

A new box for Parkinson's disease was built with dramatic speed about 15 years ago, when it was found that the distribution of dopamine in the brain did not simply parallel that of noradrenaline (Bertler, 1961). This suggested that dopamine was not merely a precursor of noradrenaline but a transmitter in its own right. Furthermore, the strikingly high dopamine concentrations in the striatum pointed to a role in the control of movement. Almost concurrently Ehringer and Hornykiewicz (1960) reported that dopamine was low in Parkinson's disease not only in the striatum but also in the substantia nigra. This linked the new biochemical findings with classical neuropathology because loss of melanin-containing cells in the substantia nigra had long been recognized as a characteristic of Parkinson's disease (Greenfield and Bosanquet, 1953). These observations were all tied together when Anden, Strombom and Svensson (1964)

\footnotetext{
* Paper presented at a Trent Regional Symposium on Parkinson's disease held at Doncaster Royal Infirmary on April 24 1976. Edited by Dr A. A. G. Lewis, and received for publication June 131977.
}

showed that causing lesions in the substantia nigra of laboratory animals led to a decrease of dopamine in the striatum.

So here was a very attractive conceptual box for Parkinson's disease in which a lesion in the substantia nigra led to a dopamine deficit in the striatum-hence to a movement disturbance. This led to a major therapeutic advance - the L-dopa treatment, but the conceptual box almost immediately started to crack-it was no longer the right shape to hold all our knowledge of Parkinson's disease.

For example, Parkinson's disease did not result when substantia nigra lesions were made in laboratory animals (Mettler, 1964). Also, at the same time that the striatal dopamine defect in the disease was found, evidence was obtained of less striking but considerable defects of two other transmitters, noradrenaline (Ehringer and Hornykiewicz, 1960) and 5-hydroxytryptamine (Bernheimer, Birkmayer and Hornykiewicz, 1961). These defects were found not only in the basal ganglia but also in the other regions. Information on disturbances of other transmitters has accumulated so that it is now difficult to consider Parkinson's disease exclusively in terms of basal ganglia dopamine metabolism and merely to mention other transmitter abnormalities in passing.

This paper will therefore deal with dopamine and other transmitters in the basal ganglia and elsewhere and with their metabolism and significance in Parkinson's disease.

\section{Transmitters in the basal ganglia}

Table 1 briefly indicates some of the more important aspects of the biochemistry of five transmitters, dopamine (DA), noradrenaline (NA), 5-hydroxytryptamine (5HT), acetylcholine (ACh) and $\gamma$ aminobutyric acid (GABA). Complete metabolic pathways and relevant literature references are given elsewhere (Curzon, 1976). Pathways of synthesis are indicated by initial precursors and rate-limiting enzymes. With the exception of 5HT synthesis the rate-limiting enzymes in the brain are almost saturated with their substrates so that (except in 
TABLE 1. Synthesis and degradation of transmitters

\begin{tabular}{|c|c|c|c|c|}
\hline \multirow{2}{*}{$\begin{array}{l}\text { Precursor } \\
\text { amino acid }\end{array}$} & \multirow{2}{*}{$\begin{array}{l}\text { Synthesis } \\
\text { Rate-limiting enzymes }\end{array}$} & \multirow[b]{2}{*}{ Transmitters } & \multicolumn{2}{|c|}{ Degradation } \\
\hline & & & Enzymes & Major terminal product \\
\hline Tyrosine & Tyrosine hydroxylase & Dopamine (DA) & $\begin{array}{l}\text { Monoamine oxidase } \\
\text { Catechol- } O \text { - } \\
\text { methyltransferase }\end{array}$ & $\begin{array}{l}\text { Homovanillic acid } \\
\text { (HVA) }\end{array}$ \\
\hline Tyrosine & $\begin{array}{l}\text { Tyrosine hydroxylase } \\
\text { Dopamine- } \beta \text {-hydroxylase }\end{array}$ & Noradrenaline (NA) & $\begin{array}{l}\text { Monoamine oxidase } \\
\text { Catechol- } O \text { - } \\
\text { methyltransferase }\end{array}$ & $\begin{array}{l}3 \text { Methoxy-4-hydroxy- } \\
\text { phenylglycol (MHPG) }\end{array}$ \\
\hline Tryptophan & Tryptophan hydroxylase & 5-Hydroxytryptamine (5HT) & Monoamine oxidase & $\begin{array}{l}5 \text { Hydroxyindole acetic } \\
\text { acid ( } 5 \text { HIAA) }\end{array}$ \\
\hline Choline & Choline acetyltransferase & Acetyl choline (ACh) & Choline esterase & Choline \\
\hline Glutamic acid & $\begin{array}{l}\text { Glutamic acid } \\
\text { decarboxylase }\end{array}$ & $\gamma$-Aminobutyric acid (GABA) & $\begin{array}{l}\text { GABA trans- } \\
\text { aminase }\end{array}$ & Various \\
\hline
\end{tabular}

N.B. This table indicates only the more important steps in transmitter synthesis and degradation.

extreme circumstances) the determination of precursor concentrations is not crucially important and transmitter synthesis cannot be much increased by giving precursors. Tryptophan however is important because the rate-limiting enzyme for 5HT synthesis is normally not saturated with it so that altering brain tryptophan concentration alters 5HT concentration or turnover.

The rate-limiting enzymes are worth determining because they are indices of the capability of the brain to manufacture corresponding transmitters and because they are localized only in the tracts containing those transmitters.

Measurement of terminal degradation products is also of interest as this gives an index of the amount of turnover of their precursor amines. One should remember, however, that the main way transmitters are removed from post-synaptic receptors is not by metabolism but by re-uptake into the nerve ending.

Table 2 indicates relative concentrations of transmitters and related substances in some basal ganglia regions. Dopamine is strikingly high and NA low and there are considerable amounts of 5HT. The metabolite of DA, homovanillic acid, on the whole parallels its parent amine (though not in the pallidum where it may originate from adjacent regions of higher dopamine concentration). Dopamine can also be detected in other regions, e.g. the median eminence, the olfactory tubercle, and the nucleus accumbens. Much recent research has concentrated on the role of the DA in the nucleus accumbens in relation to movement. Particularly active synthesis not only of DA and 5HT but also of ACh and GABA is also indicated in Table 2.

\section{Dopamine metabolism in Parkinson's disease}

Hornykiewicz's group (Table 3) found markeç deficiencies of DA and of its metabolite homovanilli acid in the parkinsonian basal ganglia. The metabo lite is proportionately rather less decreased than the parent amine. A similar difference between the DA and homovanillic acid deficits was also found when these were plotted against the extent of the lesion in the substantia nigra (Hornykiewicz, 1973). Thus, as the size of the lesion increases, dopamine level decreases, but its turnover rate increases suggesting some kind of compensatory mechanism. Comparable results have been obtained in the rat by Agid, Javoy and Glowinski (1973), who showed that a unilateral but partial lesion of the rat substantia nigra led to accelerated DA synthesis in surviving neurones of the damaged side of the brain.

In parkinsonian patients, striatal DA is already markedly decreased even when symptoms are still

TABLE 2. Distribution of some transmitters and rate-limiting enzymes in the basal ganglia*

\begin{tabular}{lccccc}
\hline & Dopamine & Noradrenaline & $\begin{array}{c}\text { 5-Hydroxy- } \\
\text { tryptamine }\end{array}$ & $\begin{array}{c}\text { Choline } \\
\text { acetyl- } \\
\text { transferase }\end{array}$ & $\begin{array}{c}\text { Glutamate } \\
\text { decarboxylase }\end{array}$ \\
\hline Caudate & +++ & $(+)$ & + & +++ & ++ \\
Putamen & +++ & $(+)$ & + & +++ & ++ \\
Pallidum & + & $(+)$ & + & ++ & ++ \\
Substantia nigra & + & $(+)$ & ++ & + & ++ \\
\hline
\end{tabular}

* Adapted from Lloyd and Hornykiewicz, 1974. 
TABle 3. Dopamine metabolism in Parkinson's disease*

\begin{tabular}{lll}
\hline & $\begin{array}{c}\text { Controls }(\mathrm{n}) \\
(\mu \mathrm{g} / \mathrm{g})\end{array}$ & $\begin{array}{c}\text { Parkinson's } \\
\text { disease }(\mathrm{n}) \\
(\mu \mathrm{g} / \mathrm{g})\end{array}$ \\
\hline $\begin{array}{l}\text { Caudate } \\
\text { DA }\end{array}$ & $\begin{array}{l}2.64(28) \\
\text { HVA }\end{array}$ & $\begin{array}{l}0.36(7) \\
0.76(7)\end{array}$ \\
$\begin{array}{l}\text { Putamen } \\
\text { DA }\end{array}$ & $3.23(8)$ & \\
$\begin{array}{l}\text { HVA } \\
\text { Pallidum }\end{array}$ & $3.44(28)$ & $0.19(7)$ \\
DA & $4.29(8)$ & $0.79(7)$ \\
HVA & $0.30(8)$ & $0.14(6)$ \\
Substantia nigra & $2 \cdot 13(8)$ & $0.72(9)$ \\
DA & $0.46(13)$ & $0.07(10)$ \\
HVA & $2.32(7)$ & $0.41(9)$ \\
\hline
\end{tabular}

* Data from Hornykiewicz (1973)

DA = dopamine; HVA = homovanillic acid.

mild (Bernheimer et al., 1973). This agrees with the concept that in early stages of the disease compensatory changes lead to the surviving neurones becoming functionally more effective. Another kind of compensatory change may also occur so that postsynaptic response to DA is enhanced. Thus, unilateral destruction of striatal DA-containing tracts in the rat increases responsiveness of dopamine receptors on the damaged side. This can be revealed by giving the DA agonist apomorphine as this causes circling movements away from the lesioned side (Ungerstedt et al., 1973). Such effects are usually interpreted as indicating a direct increase of receptor sensitivity, although this is not yet proved to be their mechanism, i.e. striatal material from lesioned animals has not been clearly shown to synthetize more cyclic AMP than material from unlesioned animals when incubated with DA. Table 4 lists various possible states of dopaminergic neurones in the parkinsonian brain. Clinically manifest Parkinsonism appears to represent a late stage in the disease process in which these compensatory changes are no longer sufficient to maintain normal neuronal function (Bernheimer et al., 1973).

As the DA defect follows the degeneration of the whole DA-containing nigrostriatal presynaptic tract, the intraneuronal enzymes required for dopamine synthesis are also markedly diminished (Table 5). Thus, the rate-limiting enzyme tyrosine hydroxylase is decreased in regions rich in dopamine

TABLE 4. Some possible functional states of dopaminergic neurones in Parkinson's disease

1. Normal neurones

2. Dead neurones

3. Compensatory changes

(a) Increased dopamine synthesis and release by surviving neurones.

(b) Increased post-synaptic responsiveness.

terminals. It is, however, also decreased in the hippocampus which is poor in DA but has considerable amounts of NA synthesis which also depends on tyrosine hydroxylase (Table 1).

Dopa decarboxylase, an intraneuronal enzyme responsible for the final step in DA synthesis but which is not rate-limiting, is also strikingly low in the parkinsonian brain in nigrostriatal regions. There is at least a suggestion that it is low in other regions including the raphe nuclei-which contain cell bodies of 5HT neurones. This could reflect a deficiency of the enzyme equipment for 5HT synthesis because the decarboxylase here is able to act not only on the 5HT precursor, 5-hydroxytryptophan, but also on dopa.

Tyrosine hydroxylase and the decarboxylating enzyme are both presynaptically localized. A completely different picture emerges when the enzymes required for catecholamine destruction are considered (Table 6). Thus, catechol- $O$-methyltransferase and monoamineoxidase activities appear

TABLE 5. Dopa decarboxylase and tyrosine hydroxylase activity in Parkinson's disease

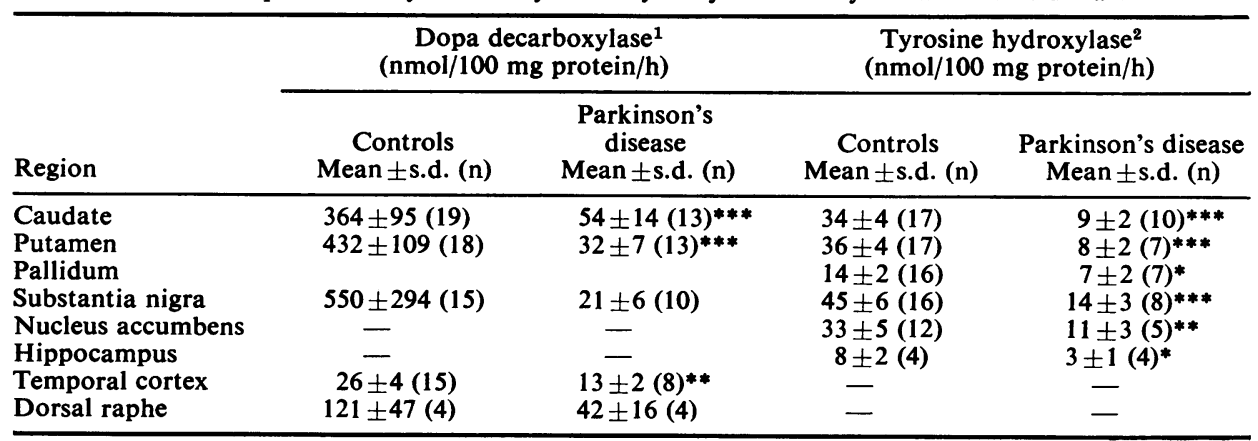

1 Data from Lloyd et al. (1973, 1975a); ${ }^{2}$ Data from McGeer and McGeer (1976).

Differences from controls: ${ }^{*} P<0.05 ;{ }^{* *} P<0.02 ; * * * P<0.01$. 
completely normal. The former enzyme occurs postsynaptically and the latter both in glial cells and presynaptically but only a small fraction occurs specifically in DA-containing neurones.

\section{Other transmitter abnormalities}

Data in Table 7 suggest considerable deficiencies of NA and 5HT not only in the basal ganglia but also elsewhere in the brain. Defective NA synthesis is hardly surprising as lesions occur not only in the parkinsonian substantia nigra where the dopamine cell bodies are largely located but also in the locus caerulus (Greenfield and Bosanquet, 1953) which contains the cell bodies of the NA-containing tracts. Defective brain 5HT metabolism is indicated by many reports of low 5-hydroxyindoleacetic acid $c$ concentration in the CSF. In particular, Guldberg $\vec{z}$ et al. (1967) found low levels in the lateral ventricular CSF in which concentrations are more closely related to brain metabolism than in the lumbar CSF, where this substance is more commonly determined.

Furthermore, there is evidence for a rather widespread deficiency of glutamate decarboxylase the rate-limiting enzyme for GABA synthesis (Table 8). Deficiency of this enzyme has been given more emphasis in Huntington's chorea than in Parkinson's

TABLE 6. Catechol-O-methyltransferase and monoamine oxidase activity in Parkinson's disease

\begin{tabular}{lcccc}
\hline & \multicolumn{2}{c}{$\begin{array}{c}\text { Catechol-O-methyl transferase } \\
(\mathrm{nmol} / 100 \mathrm{mg} \text { protein/hr) }\end{array}$} & $\begin{array}{c}\text { Monoamine oxidase } \\
(\mathrm{nmol} / 100 \mathrm{mg} \text { protein/0.5 hr) }\end{array}$ \\
\cline { 2 - 5 } Region & $\begin{array}{c}\text { Controls } \\
\text { Mean } \pm \text { s.d. (n) }\end{array}$ & $\begin{array}{c}\text { Parkinson's } \\
\text { disease } \\
\text { Mean } \pm \text { s.d. (n) }\end{array}$ & $\begin{array}{c}\text { Controls } \\
\text { Mean } \pm \text { s.d. (n) }\end{array}$ & $\begin{array}{c}\text { Parkinson's disease } \\
\text { Mean } \pm \text { s.d. (n) }\end{array}$ \\
\hline Caudate & $25 \pm 3(10)$ & $18 \pm 4(9)$ & $1730 \pm 150(10)$ & $1740 \pm 200(9)$ \\
Putamen & $24 \pm 3(11)$ & $20 \pm 4(9)$ & $1520 \pm 130(11)$ & $1650 \pm 130(10)$ \\
Substantia nigra & $26 \pm 5(5)$ & $22 \pm 10(9)$ & $1830 \pm 200(5)$ & $1480 \pm 280(4)$ \\
Cortex & $29 \pm 4(10)$ & $23 \pm 4(11)$ & $1090 \pm 110(10)$ & $1110 \pm 190(9)$
\end{tabular}

Data from Lloyd et al. (1975a). Catechol-O-methyl transferase and monoamine oxidase determined using noradrenaline and tyramine, respectively, as substrates.

TABLE 7. Noradrenaline and 5-hydroxytryptamine in Parkinson's disease

\begin{tabular}{llclc}
\hline & \multicolumn{2}{c}{ Noradrenaline $(\mu \mathrm{g} / \mathrm{g})$} & \multicolumn{2}{c}{ 5-Hydroxytryptamine $(\mu \mathrm{g} / \mathrm{g})$} \\
\cline { 2 - 4 } Region & Control & $\begin{array}{c}\text { Parkinson's } \\
\text { disease }\end{array}$ & Control & $\begin{array}{c}\text { Parkinson's } \\
\text { disease }\end{array}$ \\
\hline Caudate & $0.07(8)$ & $0.03(12)$ & $0 \cdot 33(6)$ & $0 \cdot 12(5)$ \\
Putamen & $0.11(10)$ & $0.03(12)$ & $0 \cdot 32(6)$ & $0 \cdot 14(5)$ \\
Pallidum & $0.09(6)$ & $0.11(7)$ & $0 \cdot 23(6)$ & $0 \cdot 13(5)$ \\
Substantia nigra & $0.04(11)$ & $0.02(10)$ & $0.55(6)$ & $0 \cdot 22(5)$ \\
Thalamus & $0.09(4)$ & $0.02(2)$ & $0 \cdot 26(4)$ & $0 \cdot 13(4)$ \\
Hypothalamus & $1.29(7)$ & $0.67(9)$ & $0.29(6)$ & $0 \cdot 12(5)$ \\
\hline
\end{tabular}

Data from Hornykiewicz (1964).

TABLE 8. Glutamate decarboxylase in Parkinson's disease and Huntington's chorea

\begin{tabular}{|c|c|c|c|}
\hline \multirow[b]{2}{*}{ Region } & \multicolumn{3}{|c|}{ Glutamate decarboxylase $(\mu \mathrm{mol} / 100 \mathrm{mg}$ protein $/ \mathrm{hr})$} \\
\hline & $\begin{array}{l}\text { Controls } \\
\text { Mean } \pm \text { s.d. } \\
(n=14-18)\end{array}$ & $\begin{array}{l}\text { Parkinson's } \\
\text { disease } \\
\text { Mean } \pm \text { s.d. } \\
(n=7-10)\end{array}$ & $\begin{array}{c}\text { Chorea } \\
\text { Mean } \pm \text { s.d. } \\
(n=5-7)\end{array}$ \\
\hline $\begin{array}{l}\text { Caudate } \\
\text { Putamen } \\
\text { Pallidum } \\
\text { Substantia nigra }\end{array}$ & $\begin{array}{l}4 \cdot 5 \pm 0 \cdot 5 \\
4 \cdot 7 \pm 0 \cdot 6 \\
7 \cdot 4 \pm 1 \cdot 1 \\
9 \cdot 7 \pm 1 \cdot 5\end{array}$ & $\begin{array}{l}3 \cdot 0 \pm 0 \cdot 6 \\
3 \cdot 9 \pm 0 \cdot 6 \\
2 \cdot 6 \pm 0 \cdot 4^{* * *} \\
2 \cdot 1 \pm 0 \cdot 4^{* * *}\end{array}$ & $\begin{array}{l}1 \cdot 7 \pm 0 \cdot 5^{* * *} \\
2 \cdot 2 \pm 0 \cdot 8^{*} \\
2 \cdot 3 \pm 0 \cdot 6^{* *} \\
2 \cdot 5 \pm 0 \cdot 8^{* *}\end{array}$ \\
\hline $\begin{array}{l}\text { Cortex } \\
\text { Nucleus accumbens }\end{array}$ & $\begin{array}{l}5 \cdot 4 \pm 0 \cdot 5 \\
9 \cdot 9 \pm 1 \cdot 7\end{array}$ & $\begin{array}{l}2 \cdot 9 \pm 0 \cdot 5^{* * *} \\
4 \cdot 6 \pm 1 \cdot 3\end{array}$ & $\begin{array}{l}4 \cdot 4 \pm 0 \cdot 7 \\
2 \cdot 9 \pm 0 \cdot 5^{*}\end{array}$ \\
\hline
\end{tabular}

Data from McGeer \& McGeer (1976).

Differences from controls: ${ }^{*} P<0.05$; ${ }^{* *} P<0.02$; ${ }^{* * *} P<0.01$. 
TABLe 9. Choline acetyltransferase in Parkinson's disease

\begin{tabular}{lcc}
\hline & \multicolumn{2}{c}{$\begin{array}{c}\text { Choline acetyltransferase } \\
(\mu \mathrm{mol} / \mathrm{hr} / 100 \mathrm{mg} \text { protein })\end{array}$} \\
\cline { 2 - 3 } Region & Mean \pm s.d.(n) & $\begin{array}{c}\text { Parkinson's } \\
\text { disease } \\
\text { Mean } \pm \text { s.d.(n) }\end{array}$ \\
\hline Caudate $^{1}$ & $10 \cdot 7 \pm 0 \cdot 9(15)$ & $12 \cdot 0 \pm 2 \cdot 1(9)$ \\
Nucleus accumbens $^{1}$ & $7 \cdot 5 \pm 1 \cdot 8(12)$ & $15 \cdot 9 \pm 3 \cdot 9(8)^{*}$ \\
Caudate $^{2}$ & $8 \cdot 8(3)$ & $4 \cdot 2(3)$ \\
Putamen $^{2}$ & $10 \cdot 0(3)$ & $4 \cdot 6(3)$ \\
Pallidum $^{2}$ & $1 \cdot 4(2)$ & $0 \cdot 2(3)$ \\
Substantia nigra $^{2}$ & $0 \cdot 4(6)$ & $0 \cdot 1(3)^{*}$ \\
\hline
\end{tabular}

${ }^{1}$ Data from McGeer and McGeer (1976); ${ }^{2}$ Data from Lloyd et al. (1975b)

Differences from controls: $* P<0.05$.

disease and it is interesting to compare results in the two disorders. In Huntington's chorea there is a massive deficit but apparently restricted to parts of the brain with a major dopamine innervation. Thus, the cortex as a whole contains relatively little DA and here glutamate decarboxylase is normal. In Parkinson's disease, the enzyme deficiency is considerable, not restricted to DA-rich parts of the brain and (unlike in Huntington's chorea) it occurs together with massively decreased synthesis of DA and decreases of other transmitters. Within the basal ganglia the defect is most marked in the substantia nigra and the pallidum.

Available data on cholineacetyltransferase, the rate-limiting enzyme for $\mathrm{ACh}$ synthesis, show some conflict (Table 9). Results from Lloyd et al. (1975b) suggest deficiency which seems most marked in the substantia nigra and in the pallidum (Table 8). However, their results differ from those of McGeer and McGeer (1976) who find normal values in the caudate and significantly high ones in the nucleus accumbens. These differences could be due to differences in patient selection. The many problems involved in interpreting transmitter amine data obtained on post-mortem material should also be borne in mind.

\section{Discussion}

Findings suggest that Parkinson's disease is associated not only with defective DA synthesis in the basal ganglia but also with defects in synthesis of a number of other transmitters. Many questions therefore arise. What is the significance of the DA defect in particular regions? Are the other transmitter defects sequels to that of DA or does an unknown, more primal disturbance lead to all the abnormalities? What are the neuronal interrelationships? What part do the various transmitter defects play in the development of symptoms? We can only partially answer or comment on these questions at present.
One topic which is generating much interest is the DA defect in the nucleus accumbens suggested by the low tyrosine hydroxylase activity (Table 5). Various drug experiments in animals suggest that this may have a specific role. For example, using rats rendered immobile by depleting their brain amines with reserpine, Jackson, Anden and Dahlstrom (1975) found that DA injected unilaterally into the nucleus accumbens increased co-ordinated motor activity while injection into the caudate caused stereotyped movement, such as gnawing.

Coming to the other transmitters, it now seems that NA depletion has a role in reserpine rigidity and therefore possibly in human Parkinsonism. Thus Marsden et al. (1974) found that reversal of reserpine rigidity in mice by dopa was prevented by a NA receptor antagonist phenoxybenzamine but not by the DA antagonist pimozide. Work by Anden et al. (1973) suggests that both catecholamines are required for reversal of reserpinization as they found reversal was partial with the DA agonist apomorphine and increased further by the noradrenaline agonist clonidine.

Cools and Janssen (1974) suggested that 5HT is required for post-synaptic DA response and that therefore the defective 5HT synthesis in Parkinsonism could be important. They showed that stereotyped movements in the rat after systemic injection of the DA agonist apomorphine and the contralateral turning after injecting DA into the caudate were both prevented by injection of procaine into one of the 5HT cell body-containing regionsthe nucleus linearis intermedius. This may explain some work indicating that dopa tended to be ineffective in Parkinson's disease patients who had particularly low CNS 5HT as indicated by low lumbar CSF 5-hydroxyindole acetic acid, but rather normal DA metabolism (for parkinsonian patients) as indicated by only moderately low CSF homovanillic acid (Gumpert, Sharpe and Curzon, 1973). It is also possible that low 5HT synthesis plays a part in the depression often associated with Parkinson's disease.

The GABA defect can be considered in terms of the interrelationship between dopamine and GABA neurones in the basal ganglia. As well as the nigrostriatal dopaminergic system with cell bodies in the substantia nigra and terminals in the striatum, a striato-nigral gabaminergic system exists with cell bodies in the striatum and terminals in the substantia nigra. These terminals are mostly near the zona compacta of the substantia nigra (Kananzawa et al., 1973) which contains the dopamine cell bodies. When GABA neurones fire they very probably inhibit the firing of dopamine neurones. Thus iontophoresis of GABA into the substantia nigra inhibits dopamine firing and this inhibition can be prevented by the GABA antagonist picrotoxin 
(Crossman, Walker and Woodruff, 1973). Furthermore, injection of picrotoxin into the substantia nigra causes behavioural changes like those mediated by DA (Tarsy et al., 1975). A regulating mechanism in the normal basal ganglia is therefore indicated and thus the major lesions of Parkinson's disease and Huntington's chorea can be put into a single context. Dopamine neurones may impinge not only on GABA neurones but also on other kinds of tract (Cools and Janssen, 1974; Cools and Van Rossum, 1976). If a GABA defect in Parkinson's disease leads to decreased inhibition of firing of surviving DA neurones then this could in turn lead to increased turnover rate of the DA contained in them and hence to the increased ratio of homovanillic acid to DA (Table 3). Other mechanisms for this change are also possible.

Evidence of abnormal ACh synthesis in Parkinson's disease (Table 9) is harder to interpret. McGeer et al. (1973) found that lesions between the substantia nigra and striatum do not alter choline acetyltransferase activity in either region, which is evidence against major ACh tracts between the substantia nigra and striatum. More recently, some DA terminals in the striatum were shown to be in contact with dendrites and spikes of ACh-containing neurones (Hatori et al., 1976). Interaction between DA and $\mathrm{ACh}$ neurones is consistent with pharmacological results as the DA-receptor antagonist chlorpromazine increases ACh output from the striatum (Stadler et al., 1973). This points to the possibility that dopamine normally inhibits cholinergic neurones and may explain the frequent exhibition of excessive cholinergic activity by parkinsonian patients despite the defective ACh synthesis in most basal ganglia regions found by Lloyd et al. (1975b). A rather different explanation of the increased cholinergic activity has been proposed (Spehlmann and Stahl, 1976) involving the sprouting of cholinergic neurones to replace lost DA terminals. Perhaps this explains the high choline acetyltransferase activity found in the nucleus accumbens in Parkinson's disease (McGeer and McGeer, 1976). Invasion of damaged areas by terminals of other types of neurone (Raisman and Field, 1973) could also be important.

\section{Conclusion}

If any of these various transmitter abnormalities have roles in Parkinson's disease then simply trying to reverse the DA defect will not necessarily confer striking and permanent benefit in all-or perhaps even in any patients. This, of course, agrees with clinical experience. Findings however do encourage the investigation of drugs which affect other transmitters or their receptors. It would be advantageous if their value in individual patients was predictable from biochemical findings. Unfortunately the bio- chemical investigations we can make in the living human subject are limited. As previously discussed $\underset{\mathcal{Q}}{\mathbb{Q}}$ (Garelis et al., 1974; Curzon, 1976) there are majorc. restrictions on the interpretation of data obtained on $\Rightarrow$ CSF. A hopeful but fairly distant possibility is that $\stackrel{5}{\circ}$ gradually emerging correlation of post-mortem? biochemical studies on brain material with previous $\frac{\overline{0}}{\bar{N}}$ symptoms will lead to the prediction of therapeutic $\frac{\bar{\sigma}}{\sigma}$

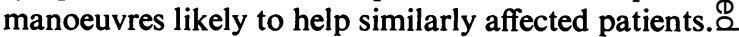

\section{References}

AgID, Y., JAvoY, F. \& Glowinski, J. (1973) Hyperactivity of remaining dopaminergic neurones after partial destruction $\vec{\omega}$ of the nigro-striatal dopaminergic system in the rat. Nature. New Biology, 245, 150.

Anden, N.E., Strombom, U. \& Svensson, T.H. (1973) Dopamine and noradrenaline receptor stimulation. reversal of reserpine-induced suppression of motor activity. $\mathrm{\omega}$ Psychopharmacologia, 29, 289.

Anden, N.E., Carlsson, A., Dahlstrom, A., Fuxe, K., N Hillarp, N.A. \& LaRSSON, K. (1964) Demonstration and? mapping out of nigro-neostriatal dopamine neurons. Life $\vec{\oplus}$ Sciences, 3, 523.

Bernheimer, H., Birkmayer, W. \& Hornykiewicz, O.을 (1961) Verteilung des 5-hydroxytryptamine (Serotonin) im_Gehirn des Menschen und sein Verhalten bei Patienten mit $\square$ Parkinson-syndrom. Klinische Wochenschrift, 39, 1056. Ф

BERNHEIMER, H., BIRKMAYer, W., HORNYKIEWICZ, O.尺 Jellinger, K. \& Seitelberger, F. (1973) Brain dopamine 3 and the syndromes of Parkinson and Huntington. Clinicad, morphological and neurochemical correlations. Journal $f^{-}$ the Neurological Sciences, $20,415$.

BERTLER, A. (1961) Occurrence and localization of cakcholamines in the brain and other tissues. Acta physiolog scandinavica, 51, 97.

Cools, A.R. \& JANSSEN, H.J. (1974) The nucleus linearis intermedius raphe and behaviour evoked by direct and indirect stimulation of dopamine-sensitive sites within the caudate nucleus of cats. European Journal of Pharmacology, 28, 266.

Cools, A.R. \& VAN Rossum, J.M. (1976) Excitation-mediating and inhibition-mediating dopamine receptors. $\overline{\mathrm{O}}$ Psychopharmacologia, 45, 243.

Crossman, A.R., Walker, R.J. \& Woodruff, G.N. (1973) Picrotoxin antagonism of gamma-aminobutyric acido inhibitory responses and synaptic inhibition in the rat substantia nigra. British Journal of Pharmacology, 49, 696. 음

Curzon, G. (1976) Transmitter amines in brain disease. In Biochemistry and Neurological Disease (Ed. by A. N.O Davison), p. 168. Blackwell, Oxford.

EHRINGER, H. \& HORNYKIEWICZ, O. (1960) Verteilung von Noradrenalin und Dopamin (3-Hydroxytyramin) in 3 Gehirn des Menschen und ihr Verhalten bei Erkrankungen des Extrapyramiden Systems. Klinische Wochenschrift, 38, 음

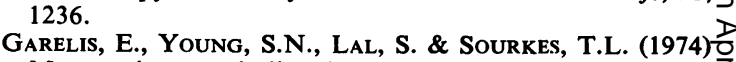
Monoamine metabolites in lumbar CSF: the question of their origin in relation to clinical studies. Brain Research, $N$.
79,1 .

Greenfield, J.G. \& Bosanquet, F.D. (1953) The brain-stem $\mathbb{O}$ lesions in Parkinsonism. Journal of Neurology, Neuro- $N$ surgery and Psychiatry, 16, 213.

Guldberg, H.C., Turner, J.W., Hanieh, A., Ashcroft, G.W., Crawford, T.B.B., Perry, W.M.L. \& Gillingham, F.J. (1967) On the occurrence of homovanillic acid and $\frac{\bar{D}}{\mathrm{D}}$ 5-hydroxyindol-3-ylacetic acid in the ventricular CSF of patients suffering from Parkinsonism. Confinia neurologica, 29, 73 . (a) 
Gumpert, E.J.W., Sharpe, D.M. \& Curzon, G. (1973) Amine metabolites in cerebrospinal fluid in Parkinson's disease and the response to L-dopa. Journal of the Neurological Sciences, 19, 1.

Hatori, T., Singh, V.K., McGeer, E.G. \& McGeer, P.L. (1976) Immunochemical localization of choline acetyltransferase containing neostriatal neurons and their relationship with dopaminergic synapses. Brain Research, $102,164$.

HoRNYKIEWICZ, O. (1964) The role of brain dopamine (3-hydroxytyramine). In: Biochemical and Neurophysiological Correlation of Centrally Acting Drugs (Proceedings of the 2nd International Pharmacological Meeting), p. 57.

HoRnykIEwICZ, O. (1973) Parkinson's disease: from brain homogenate to treatment. Federation Proceedings, 32, 183.

Jackson, D.M., ANDEn, N.E. \& Dahlstrom, A. (1975) A functional effect of dopamine in the nucleus accumbens and in some other dopamine-rich parts of the rat brain. Psychopharmacologia, 45, 139.

Kananzawa, I., Miyata, Y., Toyokura, Y. \& Otsuka, M. (1973) The distribution of $\gamma$-aminobutyric acid (GABA) in the human substantia nigra. Brain Research, 51, 363.

LlOYD, K. \& HORNYKIEWICZ, O. (1974) Dopamine and other monoamines in the basal ganglia: relation to brain dysfunction. In: Frontiers in Neurology and Neuroscience Research (Ed. by P. Seeman and G. M. Brown), p. 26. University of Toronto.

Lloyd, K.G., Davidson, L. \& HoRnYkiewicz, O. (1973) Metabolism of levodopa in the human brain. Aavances in Neurology, 3, 173.

Lloyd, K.G., Davidson, L. \& Hornykiewicz, O. (1975a) The neurochemistry of Parkinson's disease: effect of L-dopa therapy. The Journal of Pharmacology and Experimental Therapeutics, 195, 453.

Lloyd, K.G., Mohler, H., Heitz, P. \& Bartholini, G. (1975b) Distribution of choline acetyltransferase and glutamate decarboxylase within the substantia nigra and in other brain regions from control and Parkinsonian patients. Journal of Neurochemistry, 25, 789.

Marsden, C.D., Dolphin, A., Duvoisin, R.C., Jenner, P. \& TARSY, D. (1974) Role of noradrenaline in levodopa reversal of reserpine akinesia. Brain Research, 77, 521.

MCGeer, P.L. \& McGeer, E.G. (1976) Enzymes associated with the metabolism of catecholamines, acetylcholine and GABA in human controls and patients with Parkinson's disease and Huntington's chorea. Journal of Neurochemistry, 26, 65.

MCGeer, E.G., Fibiger, H.C., McGeer, P.L. \& Brooke, S. (1973) Temporal changes in amine synthesizing enzymes of rat extrapyramidal structures after hemitransections or 6-hydroxydopamine administration. Brain Research, 52, 289.

Mettler, G.A. (1964) Substantia nigra and Parkinsonism. Archives of Neurology, 11, 529.

Raisman, G. \& FielD, P.M. (1973) A quantitative investigation of the development of collateral reinnervation after partial deafferentation of the septal nuclei. Brain Research. 50, 241.

SpehlmanN, R. \& Stahl, S.M. (1976) Dopamine acetylcholine imbalance in Parkinson's disease. Possible regenerative overgrowth of cholinergic axon terminals. The Lancet, i, 724.

Stadler, H., Lloyd, K.G., Gadea-Ciria, M. \& Bartholini, G. (1973) Enhanced striatal acetylcholine release by chlorpromazine and its reversal by apomorphine. Brain Research, 55, 476.

Tarsy, D., Pycock, C., Meldrum, B. \& Marsden, C.D. (1975) Rotational behaviour induced in rats by intranigral picrotoxin. Brain Research, 89, 160.

Ungerstedt, U., Avemo, A., LuUngberg, T. \& Ranje, C. (1973) Animal models of Parkinsonism. Advances in Neurology, 3, 257. 